\title{
Does Exposure to Agricultural Chemicals Increase the Risk of Prostate Cancer among Farmers?
}

\author{
Marie-Élise Parent*, Marie Désy, and Jack Siemiatycki
}

\begin{abstract}
Several studies suggest that farmers may be at increased risk of prostate cancer. The present analysis, based on a large population-based case-control study conducted among men in the Montreal area in the early 1980 's, aim at identifying occupational chemicals which may be responsible for such increases. The original study enrolled 449 prostate cancer cases, nearly 4,000 patients with other cancers, as well as 533 population controls. Subjects were interviewed about their occupation histories, and a team of industrial hygienists assigned their past exposures using a checklist of some 300 chemicals. The present analysis was restricted to a study base of men who had worked as farmers earlier in their lives. There were a total of 49 men with prostate cancers, 127 with other cancers and 56 population controls. We created a pool of 183 controls combining the patients with cancers at sites other than the prostate and the population controls. We then estimated the odds ratio for prostate cancer associated with exposure to each of $\mathbf{1 0}$ agricultural chemicals, i.e., pesticides, arsenic compounds, acetic acid, gasoline engine emissions, diesel engine emissions, polycyclic aromatic hydrocarbons from petroleum, lubricating oils and greases, alkanes with $\geq 18$ carbons, solvents, and mononuclear aromatic hydrocarbons. Based on a model adjusting for age, ethnicity, education, and respondent status, there was evidence of a two-fold excess risk of prostate cancer among farmers with substantial exposure to pesticides [odds ratio $(\mathrm{OR})=\mathbf{2 . 3}, \mathbf{9 5} \%$ confidence interval $(\mathrm{CI}) \mathbf{1 . 1 - 5 . 1}$, as compared to unexposed farmers. There was some suggestion, based on few subjects, of increased risks among farmers ever exposed to diesel engine emissions $(\mathrm{OR}=5.7,95 \% \mathrm{CI} 1.2-26.5)$. The results for pesticides are particularly noteworthy in the light of findings from previous studies. Suggestions of trends for elevated risks were noted with other agricultural chemicals, but these are largely novel and need further confirmation in larger samples.
\end{abstract}

\section{INTRODUCTION}

Prostate cancer is the most frequently occurring cancer among Canadian men.(1) Despite extensive research, the etiology of this disease remains poorly understood. Only a few risk factors for prostate cancer have been clearly established to date including age, a positive family history of the disease, and ethnicity. The normal function of the prostate is controlled by testosterone, and androgenic stimulation of the prostate over a prolonged period may promote or initiate carcinogenesis. $(2,3)$ The prostate gland is also sensitive

*To whom correspondence should be addressed:

Marie-Élise Parent, Ph.D.

Associate Professor, Epidemiology and Biostatistics Unit

INRS-Institut Armand-Frappier

531, Boul. des Prairies

Laval, Quebec, Canada. H7V 1B7

Email: marie-elise.parent@iaf.inrs.ca to estrogens.(4) Administration of estrogens reduces testosterone production, and is used to control disseminated prostate cancer. However, there is epidemiologic and experimental evidence suggesting that estrogenic hormones may cause DNA damage and initiate prostate cancer.(5-9) Taken together, these observations suggest that both androgens and estrogens are associated with the risk of prostate cancer, and that exogenous factors that could influence hormone levels could play an etiological role. The large gradients in risks across ethnic groups, geographical areas and the evidence from migrant studies point out to a strong, as yet undefined, influence of environmental factors.(10) It is thought that prostate cancer could result from a complex interplay between several environmental, lifestyle and genetic factors. (10-13)

The possible etiologic role of environmental factors, such as those encountered in the workplace, has been 
reviewed.(12) A large number of studies have assessed the risk of prostate cancer in various occupation groups. Most of them were based exclusively on job titles, providing only indirect evidence of the underlying risk factors. There are some hints that occupational groups potentially exposed to pesticides, which include farmers but also pesticide manufacturers, workers exposed to metalworking-related substances, workers exposed to diesel engine emissions, to polycyclic aromatic hydrocarbons $(\mathrm{PAH})$ and to cadmium might experience excess risks. The evidence is reviewed briefly here.

Farming, pesticides and herbicides: One puzzling observation is the generally consistent pattern for an excess risk of prostate cancer among farmers.(12) At least 100 studies have examined the relationship between farming (as a job title) and prostate cancer. Results from meta-analyses based on these are consistent with a weak, positive association.(14-17) However, with a summary relative risk of about 1.1, chance cannot be ruled out with certainty. The association might also reflect some systematic bias, possibly publication bias. Finally the positive association might reflect lifestyle factors or environmental factors such as occupational exposures. The slight excess of prostate cancers contrasts with low risks for most other cancers and non-neoplastic diseases among farmers.(14) The interpretation of this body of evidence remains uncertain.(18)

Very few studies to date have considered, other than in a very crude way, the role of specific chemical agents in the farmers' environment. Because several pesticides are estrogen-like compounds that can modulate hormone levels,(19) these agents are under particular suspicion. Yet the evidence for a putative role of pesticides in prostate cancer etiology is still very limited. Use of pesticides has been associated with prostate cancer in some(20-27) but not all studies.(2832) Discordant evidence concerning hazards due to pesticides also comes from studies of workers involved in manufacturing or spraying of these compounds(3342), and pesticide applicators.(4,43-55) Most of these studies were quite small. Early reports from the Agricultural Health Study Cohort regarding chlorinated pesticides are conflicting. $(56,57)$ Finally, in a few studies, $(58,59)$ but not all, $(23,25,29,60)$ elevated risks for workers exposed to fertilisers have been reported. Genetic susceptibility might modify prostate cancer risk from pesticide exposure. $(61,62)$

Farming can involve a wide range of activities, including equipment operating, mechanical maintenance and repair, soldering, carpentry, livestock handling, pesticide, fertilizer application, etc. These can entail potential exposures to very diverse agents such as solvents, fuels and oils, metal dusts, welding fumes, engine exhausts, paints, pesticides, herbicides, insecticides, fertilizers, zoonotic viruses, microbes, fungi, organic dusts, and sunlight. For most of these, evidence with regard to prostate cancer is lacking.

Metalworking-related exposures: Metal workers such as mechanics, repairmen, and machine operators may be at increased risks of prostate cancer.(63-65) However, in few studies were specific exposures examined. Among those that did, there was some evidence of associations with some metallic dusts and with metalworking chemicals, such as solvents, cutting oils, mineral oils, heating oils, hydraulic fluids, lubricating oils and acids.(64,66-69) These findings were not always replicated, however.(32)

PAH and engine emissions: There is some evidence, albeit not entirely consistent,(70) of excess risks in occupational groups with potential exposure to PAHs.(66,71-77) In a few studies that entailed substance-based exposure assessment protocols, one found excess risks in relation to liquid fuel combustion products and PAH as a class,(66) and another(78) found excess risk in relation to diesel fuel and fumes, soot, tar and pitch. Contrasting results, suggesting no association with PAHs or diesel fumes, have been reported as well. $(32,67)$ Diesel engine emissions may induce changes in enzymatic activities in the prostate glands of animals. $(78,79)$ In addition, the anti-estrogenic effects of certain hydrocarbons, such as benzo(a)pyrene, may promote the growth of prostate cancer cells. Several PAHs may interact with estrogen receptor signalling.(80)

Cadmium: Cadmium is found in some insecticides and fertilisers, and exposure can occur in several workplaces. Other sources include diet and tobacco smoke.(77) Following some early reports of excess risk of prostate cancer among cadmium-exposed workers, more recent and larger studies failed to confirm these.(81-83) Nevertheless, experimental data suggest that prostatic tumours can be induced experimentally in rodents by oral exposure to cadmium.(84)

Overall, the available evidence on occupational factors remains limited. The vast majority of studies of occupational circumstances and prostate cancer conducted to date were retrospective mortality studies in which job or industry titles as recorded on death certificates were used as indices of exposure. Although such studies are useful in providing leads, what is really needed are studies of occupational factors based on refined exposure assessment protocols. $(18,85)$

One of the most detailed and in-depth evaluations of the association between occupational exposures and prostate cancer has been carried out by our research group through analyses of our multiple-site, casecontrol study conducted in Montreal in the 
1980s.(86,87) Several occupational substances exhibited moderately strong associations with prostate cancer, including metallic dust, liquid fuel combustion products, lubricating oils and greases, and PAH from coal.(66) Estimates of the proportion of prostate cancer cases in the population that would be attributable to occupational exposures ranged from 12 to 21 percent. These figures may have been somewhat overestimated and precision was low. Still, even if the true attributable fraction were in the range of 5 to $10 \%$, it would represent an important public health issue. Interestingly, we have recently found a similar pattern of risk in relation to prostate cancer for exposure to some of these substances during leisure-time activities.(88)

In order to further investigate the role of agricultural exposures in prostate cancer, we conducted a new analysis of the aforementioned Montreal-based study, this time focusing on men, both cases and controls, with a history of farming. Results from these analyses are reported here.

\section{MATERIALS AND METHODS}

\section{Study sample}

In the 1980s, our research group undertook a large population-based case-control study in Montreal to explore the relationship between hundreds of occupational exposures and 19 cancer sites. This study has been described in detail elsewhere.(86) Briefly, nearly 4,000 incident cancer cases, all males, were recruited, including 449 prostate cancer patients. A group of 533 population controls, frequency matched on age and residential area to the cancer patients, was also interviewed.

For the purpose of the present analyses, we restricted the case series to those 49 prostate cancer cases who had ever been farmers, and constituted a control series of 183 men who had also been farmers (combining 56 population controls and 127 patients with cancer at a site other than the prostate). No cancer type represented more than $20 \%$ of the entire group of 127 cancer patients.

\section{Data collection}

Data were collected as part of face-to-face interviews. Information was collected on socio-demographic factors and lifestyle. A semi-structured questionnaire was used to obtain a detailed description of each job held by each subject over his lifetime. Trained interviewers probed for details about work activities, raw material used, work environment, etc. A team of expert chemists and industrial hygienists then reviewed each reported job and inferred the potential exposure to 294 chemical agents.
For each exposure thought to be present in the worker's environment, the team of chemists had to describe the degree of certainty that the exposure actually occurred (whether it was possible, probable or definite), the frequency of exposure (less that $5 \%$ of time in a normal work-week, 5 to $30 \%$ of time, or more than $30 \%$ ), the relative concentration of the exposure (low, medium or high), and the number of years of exposure.

\section{Data analysis}

Unconditional logistic regression was used to model the risk of developing prostate cancer associated with exposure to the selected chemicals during farming. Potential confounders entered into the regression models included age (years), ethnicity (French / Anglo / Italian / Other European / Other), educational level (years), and respondent status (self / proxy).

Ten chemicals were retained for analysis. Firstly, we selected 4 substances which had at least 20\% lifetime prevalence of exposure among controls, and which were either of a priori interest based on studies of occupational groups, i.e., pesticides, diesel engine emissions, PAH from petroleum, and lubricating oils and greases. Secondly, we expanded the list of chemicals to be studied to include 6 other substances who had so-called suggestive odds ratios in this database, defined here as 1.3 or more. These were: arsenic compounds, acetic acid, gasoline engine emissions, alkanes with 18 carbons or more, solvents, and MAH.

Only those subjects categorized as "probably" or "definitely" exposed to the selected agricultural chemicals by the expert chemists/hygienists were considered as exposed. Moreover, we excluded from the analyses those subjects who had been exposed only in the 5 years before diagnosis or enrolment in the study.

We first conducted analyses categorizing subjects as never or ever exposed to the agricultural chemicals under study. For pesticides, for which there were sufficient numbers, we further restricted our analysis to a subset of subjects with "substantial" exposure, defined as having a medium or high frequency of exposure, a medium or high concentration of exposure and a duration of exposure greater than 5 years. Finally, we assessed the risk of prostate cancer associated with increasing concentration, frequency, and duration of exposure to pesticides.

\section{RESULTS}

Farmers with prostate cancer were more often of French ancestry than control farmers (Table 1). Cases and controls differed marginally in terms of educational level and respondent status. Seventy nine percent of 


\begin{tabular}{|l|r|r|}
\hline Characteristics & \multicolumn{1}{|c|}{ Cases } & \multicolumn{1}{c|}{ Controls } \\
\hline Mean age (years) & 63 & 61 \\
\hline Ethnicity (\%) & 78 & 56 \\
\hline French & 2 & 7 \\
\hline Anglo & 12 & 22 \\
\hline Italian & 8 & 13 \\
\hline Other European & 0 & 2 \\
\hline Other & 8 & 7 \\
\hline Mean educational level (years) & 14 & 17 \\
\hline Proxy respondents (\%) & & \\
\hline
\end{tabular}

Table 1. Characteristics of the 49 case farmers and 183 control farmers

farming occupations reported in this study population were as farm workers or farm labourers, while $21 \%$ were as farm manager, foreman or owner.

Subjects categorized here as exposed had been exposed only during farming, and never in other jobs held by farmers. There were in fact four substances which were exclusive to farming, namely pesticides, arsenic compounds, acetic acid and diesel engine emissions, which means that they were never encountered in other jobs that the farmers had held.

Table 2 shows the risk estimates for prostate cancer associated with ever exposure to the selected substances. Odds ratios were slightly elevated for all 10 chemicals studied, although only diesel engine emissions achieved statistical significance.

For pesticides (Table 3), we also assessed risks associated with exposure at the substantial level, as well as according to the different dimensions of exposure. Farmers with substantial exposure to pesticides had a significant, two-fold excess in risk, compared to unexposed farmers. The risk increased slightly with increasing frequency and duration of exposure. Nearly all exposures to pesticides were rated at the medium concentration level, precluding an evaluation of the risks with increasing concentration levels.

\section{DISCUSSION}

Results from this analysis offer a glimpse at the role of pesticides on the risk of prostate cancer among farmers. One particular characteristic of this study is that it was based on both case and control farmers. Farmers tend to have a specific lifestyle related to their work activities. Nearly all previous studies of farmers and prostate cancer have used non-farmers as controls. Our approach might have made our cases and controls more homogeneous in terms of their lifestyle habits, thereby providing some internal adjustment for potential as yet undefined lifestyle-related risk factors for prostate cancer. However, by doing so, we might have attenuated our chances of observing differences in risks associated with chemical exposures. For this reason, the odds ratios estimated here possibly represent conservative estimates of risk.

Advantages of the study include the detailed exposure assessment scheme, based on expert judgment, carried out on a case-by-case basis, and based on in-person interviews eliciting detailed job description and work practices. This exposure assessment approach is recognized as the reference method for such as study design.(89) Moreover, prostate cancer cases were incident cases, we had access to different control groups, and were able to adjust for some potential confounders.

The main limitation of this analysis is the small number of farmers it is based on, owing to the population-based nature of the study. We had no information on dietary habits. However, because this analysis was restricted to farmers, cases and controls might have been relatively comparable in this respect.

The types of pesticides used were not systematically elicited from the subjects. However, among those who volunteered the information, the most common types were "Paris Green" (a mixture of lead arsenate, acetic acid, and mineral oil), lime (calcium oxide), DichloroDiphenil-Tricholoethane, and "Bouillie Bordelaise" (a mixture of copper sulfate and lime).

Investigating prostate cancer risks in relation to occupational exposures is important because exposure levels in the workplace may be higher than in the general environment and because most workplace substances find their way into the general

\begin{tabular}{|l|r|r|r|}
\hline Exposure & $\mathbf{N}_{\mathbf{c a}}$ & OR & $\mathbf{9 5 \%} \mathbf{C I}$ \\
\hline Pesticides & 25 & 1.4 & $0.7-2.7$ \\
\hline Arsenic compounds & 15 & 1.4 & $0.6-3.0$ \\
\hline Acetic acid & 12 & 1.5 & $0.7-3.4$ \\
\hline Gasoline engine emissions & 5 & 1.3 & $0.4-4.5$ \\
\hline $\begin{array}{l}\text { Diesel engine emissions } \\
\text { Polycyclic aromatic hydrocarbons from } \\
\text { petroleum }\end{array}$ & 5 & 5.7 & $1.2-26.5$ \\
\hline Lubricating oils and greases & 6 & 1.4 & $0.3-5.8$ \\
\hline Alkanes with $\geq \mathbf{1 8}$ carbons & 9 & 1.5 & $0.6-4.0$ \\
\hline Solvents & & 1.8 & $0.7-5.0$ \\
\hline \begin{tabular}{l} 
Mononuclear aromatic hydrocarbons \\
\hline
\end{tabular} & 6 & 1.7 & $0.5-5.4$ \\
\hline
\end{tabular}

Table 2. Odds ratio (OR)* and $95 \%$ confidence interval (CI) for prostate cancer associated with ever exposure to selected chemicals during farming

*Adjusted for age, ethnicity, education, respondent status 
environment.(85) Understanding whether occupational chemicals cause prostate cancer is important not only for prevention, but it can also contribute to an understanding of carcinogenesis. While there is still limited physiologic evidence on the extent to which different exogenous chemicals may affect the prostate gland, it is known that some chemicals (i.e., dioxins, diesel emissions) can alter enzymatic activity in the prostate. $(79,90)$ Exposure to certain chemicals such as cadmium can induce prostate tumours in animals.(91)

A great deal of interest is being directed towards the hypothesis that certain environmental chemicals may act as endocrine disruptors or modulators.(2$4,19,92,93)$ Exposure during development and adult years could be relevant.(94) The effects may be due to their a) mimicking endogenous hormones such as estrogens and androgens, b) antagonising endogenous hormones, c) altering the pattern of synthesis and metabolism of hormones, and/or d) modifying hormone receptors levels. As hormonal influences are likely related to prostate cancer etiology, hormone-modulating exogenous chemicals are of particular interest.(95) Several industrial chemicals have been associated with endocrine-disrupting effects including some metals (cadmium, lead, mercury, aluminium), phenolic derivatives (phenol, bisphenol-A, pentachlorophenol, resorcinol, PCBs), phthalates (used as plasticizers), variously substituted benzenes (polycyclic aromatic hydrocarbons [PAH], benzo[a]pyrene), styrenes (used in the manufacture of plastics and rubber), carbon disulphide (used in the production of rayon), dioxin, and several organochlorine pesticides, fungicides and herbicides. $(93,96-100)$ Extremely low exposures to some endocrine modulators (plasticizers, alkylphenols) have been found to induce adverse effects on the male reproductive tract of rodents.(100) Considerable

\begin{tabular}{|l|r|r|r|}
\hline Pesticides & \multicolumn{1}{|c|}{$\mathbf{N}_{\mathbf{c a}}$} & \multicolumn{1}{c|}{ OR } & \multicolumn{1}{|c|}{$\mathbf{9 5 \%}$ CI } \\
\hline Level of exposure & & & \\
\hline Any & 25 & 1.4 & $0.7-2.7$ \\
\hline Substantial & 17 & 2.3 & $1.1-5.1$ \\
\hline Frequency of exposure & & & \\
\hline Low & 7 & 0.9 & $0.3-2.3$ \\
\hline Medium or high & 18 & 1.7 & $0.8-3.6$ \\
\hline Duration of exposure & & & \\
\hline Up to 10 years & 11 & 1.2 & $0.5-2.8$ \\
\hline More than 10 years & 14 & 1.5 & $0.7-3.4$ \\
\hline
\end{tabular}

Table 3: Odds ratio $(\mathrm{OR})^{*}$ and $95 \%$ confidence interval (CI) for prostate cancer associated with exposure to pesticides during farming by level, frequency and duration of exposure

*Adjusted for age, ethnicity, education, respondent status concentrations of chlorinated hydrocarbons can accumulate in the male genital tract, in the reception zone for spermatozoa.(101) Also, endogenous estrogens are bound to the sex hormone-binding globulin while many exogenous estrogens are not, resulting in higher concentrations of free compounds.(19) Taken together, this body of evidence suggests that exposure to a wide variety of exogenous chemicals would modulate hormone levels, which in turn, could influence prostate cancer development.

\section{CONCLUSION}

In conclusion, farmers exposed to high levels of pesticides had a two-fold excess risk of prostate cancer compared to unexposed farmers. Exposure to diesel engine emissions was also associated with elevated risks, but statistical precision was low. Hints of excess risks were noted for other chemicals. Some of these tended to be correlated to one another, which would explain why risk estimates were similar for several of the chemicals studied. For instance, arsenic compounds and acetic acid are common ingredients in some pesticides. Conversely, activities involving agricultural machinery repairs would be expected to entail conjoint exposure to several chemicals such as lubricating oils and greases, solvents and engine emissions.

The results presented here are based on a limited sample. Nevertheless, in light of the accruing epidemiological and experimental evidence, further exploration around these potential associations is warranted. The Agricultural Health Study, a US-based prospective cohort study initiated in 1993, currently follows a large group of pesticides applicators from Iowa and North Carolina. It is hoped that upcoming results from this large study will shed light on the health risks, including prostate cancer, incurred by agricultural workers.

\section{REFERENCES}

1. Canadian Cancer Society/National Cancer Institute of Canada. Canadian Cancer Statistics 2007. Toronto: Canadian Cancer Society/National Cancer Institute of Canada, 2007.

2. Ross R, Schottenfeld D. Prostate cancer. In: Schottenfeld D, Fraumeni J, Jr. editors. Cancer Epidemiology and Prevention. 2nd ed. New York: Oxford University Press; 1996. p. 1180-206.

3. Brawley OW, Knopf K, Thompson I. The epidemiology of prostate cancer part II: the risk factors. Semin Urol Oncol 1998; 16:193-201.

4. Dich J, Wiklund K. Prostate cancer in pesticide applicators in Swedish agriculture. Prostate 1998; 34:100-12.

5. Carruba G. Estrogens and mechanisms of prostate cancer progression. Ann N Y Acad Sci 2006;1089:201-17.

6. Ho SM, Leung YK, Chung I. Estrogens and antiestrogens as etiological factors and therapeutics for prostate cancer. Ann N Y Acad Sci 2006;1089:177-93.

7. Prezioso D, Denis LJ, Klocker H, Sciarra A, Reis M, Naber K et al. Estrogens and aspects of prostate disease. Int J Urol 
2007;14:1-16

8. Weihua Z, Makela S, Andersson LC, Salmi S, Saji S, Webster JI et al. A role for estrogen receptor beta in the regulation of growth of the ventral prostate. Proc Natl Acad Sci U S A 2001;98:63305 .

9. Harkonen PL, Makela SI. Role of estrogens in development of prostate cancer [Review]. J Steroid Biochem Mol Biol 2004;92:297-305

10. Hsing AW, Chokkalingam AP. Prostate cancer epidemiology [Review]. Front Biosci 2006;11:1388-413.

11. Wigle D, Turner M, Gomes J, Parent ME. Role of hormonal and other factors in human prostate cancer [Review]. J Toxicol Environ Health B Crit Rev 2008;11:242-59.

12. Parent M, Siemiatycki J. Occupation and prostate cancer [Review]. Epidemiol Rev 2001; 23:138-43.

13. Chokkalingam AP, Stanczyk FZ, Reichardt JKV, Hsing AW. Molecular epidemiology of prostate cancer: hormone-related genetic loci [Review]. Front Biosci 2007;12:3436-60.

14. Blair A, Zahm SH, Pearce NE, Heineman EF, Fraumeni JF. Clues to cancer etiology from studies of farmers. Scand J Work Environ Health 1992;18:209-15.

15. Keller-Byrne JE, Khuder SA, Schaub EA. Meta-analyses of prostate cancer and farming. Am J Ind Med 1997;31:580-6.

16. Acquavella J, Olsen G, Cole P, Ireland B, Kaneene J, Schuman $\mathrm{S}$ et al. Cancer among farmers - a meta-analysis [Review]. Ann Epidemiol 1998;8:64-74.

17. Van Maele-Fabry G, Willems JL. Occupation related pesticide exposure and cancer of the prostate: a meta-analysis. Occup Environ Med 2003;60:634-42.

18. Acquavella J. Farming and prostate cancer. Epidemiol 1999;10:349-51.

19. Golden RJ, Noller KL, Titus-Ernstoff L, Kaufman RH, Mittendorf R, Stillman R et al. Environmental endocrine modulators and human health: an assessment of the biological evidence. Crit Rev Toxicol 1998;28:109-227.

20. Burmeister LF, Everett GD, Van Lier SF, Isacson P. Selected cancer mortality and farm practices in Iowa. Am J Epidemiol 1983;118:72-7.

21. Meyer TE, Coker AL, Sanderson M, Symanski E. A case-control study of farming and prostate cancer in African-American and Caucasian men. Occup Environ Med 2007; 64:155-60.

22. Parent ME, Siemiatycki J, Desy M. Case-control study of occupational exposures and risk of prostate cancer among farmers (abstract). Am J Epidemiol 2001;153:S264.

23. Morrison H, Savitz D, Semenciw R, Hulka B, Mao Y, Morison $\mathrm{D}$ et al. Farming and prostate cancer mortality. Am J Epidemiol 1993;137:270-80.

24. Forastiere F, Quercia A, Miceli M, Settimi L, Terenzoni B, Rapiti E et al. Cancer among farmers in central Italy. Scand J Work Environ Health 1993;19:382-9.

25. van der Gulden JWJ, Kolk JJ, Verbeek ALM. Work environment and prostate cancer risk. Prostate 1995;27:250-7.

26. Mills P, Yang R. Prostate cancer risk in California farm workers. J Occup Environ Med 2003;45:249-58.

27. Settimi L, Masina A, Andrion A, Axelson O. Prostate cancer and exposure to pesticides in agricultural settings. Int $\mathrm{J}$ Cancer 2003;104:458-61.

28. Delzell E, Grufferman S. Mortality among white and nonwhite farmers in North Carolina, 1976-1978. Am J Epidemiol 1985;121:391-402.

29. Saftlas AF, Blair A, Cantor KP, Hanrahan L, Anderson HA. Cancer and other causes of death among Wisconsin farmers. Am J Ind Med 1987;11:119-29.

30. Fincham SM, Hanson J, Berkel J. Patterns and risks of cancer in farmers in Alberta. Cancer 1992;69:1276-85.

31. Hessel PA, Kalmes R, Smith TJ, Lau E, Mink PJ, Mandel J. A nested case-control study of prostate cancer and atrazine exposure. J Occup Environ Med 2004;46:379-85.

32. Boers D, Zeegers MPA, Swaen GM, Kant IJ, van den Brandt PA. The influence of occupational exposure to pesticides, polycyclic aromatic hydrocarbons, diesel exhaust, metal dust, metal fumes, and mineral oil on prostate cancer: a prospective cohort study. Occup Environ Med 2005;62:531-7.

33. Lynge E. A follow-up study of cancer incidence among workers in manufacture of phenoxy herbicides in Denmark. Br J Cancer 1985;52:259-70.

34. Coggon D, Pannett B, Winter PD, Acheson ED, Bonsall J. Mortality of workers exposed to 2 methyl-4 chlorophenoxyacetic acid. Scand J Work Environ Health 1986;12:448-54.

35. Olsen JH, Jensen OM. Occupation and risk of cancer in Denmark. An analysis of 93,810 cancer cases, 1970-1979. Scand J Work Environ Health 1987;13(Suppl 1):1-91.

36. Ott MG, Olson RA, Cook RR, Bond GG. Cohort mortality study of chemical workers with potential exposure to the higher chlorinated dioxins. J Occup Med 1987;29:422-9.

37. Manz A, Berger J, Dwyer JH, Flesch-Janys D, Nagel S, Waltsgott H. Cancer mortality among workers in chemical plant contaminated with dioxin [see comments]. Lancet 1991;338:959-64.

38. Acquavella JF, Riordan SG, Anne M, Lynch CF, Collins JJ, Ireland $\mathrm{BK}$ et al. Evaluation of mortality and cancer incidence among alachlor manufacturing workers. Environ Health Perspect 1996;104:728-33.

39. Wilkinson P, Thakrar B, Shaddick G, Stevenson S, Pattenden S, Landon $\mathrm{M}$ et al. Cancer incidence and mortality around the Pan Britannica Industries pesticide factory, Waltham Abbey. Occup Environ Med 1997;54:101-7.

40. de Jong G, Swaen GMH, Slangen JJM. Mortality of workers exposed to dieldrin and aldrin - a retrospective cohort study. Occup Environ Med 1997;54:702-7.

41. Van Maele-Fabry G, Willems JL. Prostate cancer among pesticide applicators: a meta-analysis. Int Arch Occup Environ Health 2004;77:559-70.

42. van Maele-Fabry G, Libotte V, Willems J, Lison D. Review and meta-analysis of risk estimates for prostate cancer in pesticide manufacturing workers [Review]. Cancer Causes Control 2006;17:353-73.

43. Riihimaki V, Asp S, Hernberg S. Mortality of 2,4dichlorophenoxyacetic acid and 2,4,5-trichlorophenoxyacetic acid herbicide applicators in Finland: first report of an ongoing prospective cohort study. Scand J Work Environ Health 1982;8:37-42.

44. Rusiecki JA, Hou LF, Lee WJ, Blair A, Dosemeci M, Lubin JH et al. Cancer incidence among pesticide applicators exposed to metolachlor in the Agricultural Health Study. Int J Cancer 2006;118:3118-23.

45. Blair A, Grauman DJ, Lubin JH, Fraumeni JF, Jr. Lung cancer and other causes of death among licensed pesticide applicators. J Nat Cancer Inst 1983;71:31-7.

46. Wiklund K, Dich J, Holm LE, Eklund G. Risk of cancer in pesticide applicators in Swedish agriculture. $\mathrm{Br} \mathrm{J}$ Ind Med 1989;46:809-14.

47. Cantor KP, Booze Jr CF. Mortality among aerial pesticide applicators and flight instructors: a reprint. Arch Environ Health 1991;46:110-6.

48. Figa-Talamanca I, Mearelli I, Valente P, Bascherini S. Cancer mortality in a cohort of rural licensed pesticide users in the Province of Rome. Int J Epidemiol 1993;22:579-83.

49. Asp S, Riihimaki V, Hernberg S, Pukkala E. Mortality and cancer morbidity of Finnish chlorophenoxy herbicide applicators - an 18-year prospective follow-up. Am J Ind Med 
1994;26:243-53.

50. Torchio P, Lepore AR, Corrao G, Comba P, Settimi L, Belli S et al. Mortality study on a cohort of Italian licensed pesticide users. Sc Total Environ 1994;149:183-91.

51. Zhong Y, Rafnsson V. Cancer incidence among Icelandic pesticide users. Int J Epidemiol 1996;25:1117-24.

52. Fleming L, Bean J, Rudolph M, Hamilton K. Cancer incidence in a cohort of licensed pesticide applicators in Florida. J Occup Environ Med 1999;41:279-88.

53. Fleming LE, Bean JA, Rudolph M, Hamilton K. Mortality in a cohort of licenced pesticide applicators in Florida. Occup Environ Med 1999;56:14-21.

54. Wesseling C, Antich D, Hogstedt C, Rodriguez A, Ahlbom A. Geographical differences of cancer incidence in Costa Rica in relation to environmental and occupational pesticide exposure. Int J Epidemiol 1999;28:365-74.

55. Pavuk M, Michalek JE, Ketchum NS. Prostate cancer in US Air Force veterans of the Vietnam war. J Expos Sci Environ Epidemiol 2006;16:184-90.

56. Alavanja M, Samanic C, Dosemeci M, Lubin J, Tarone R, Lynch $\mathrm{C}$ et al. Use of agricultural pesticides and prostate cancer risk in the Agricultural Health Study cohort. Am J Epidemiol 2003;157:800-14.

57. Purdue MP, Hoppin JA, Blair A, Dosemeci M, Alavanja MCR. Occupational exposure to organochlorine insecticides and cancer incidence in the Agricultural Health Study. Int J Cancer 2007;120:642-9.

58. Rotkin ID. Studies in the epidemiology of prostatic cancer: expanded sampling. Cancer Treat Rep 1977;61:173-80.

59. Hagmar L, Bellande T, Andersson C, Linden K, Attewell R, Moller T. Cancer morbidity in nitrate fertilizer workers. Int Archi Occup Environ Health 1991;63:63-7.

60. Zandjani F, Hogsaet B, Andersen A, Langard S. Incidence of cancer among nitrate fertilizer workers. Int Arch Occup Environ Health 1994;66:189-93.

61. Mahajan R, Bonner MR, Hoppin JA, Alavanja MCR. Phorate exposure and incidence of cancer in the agricultural health study. Environ Health Perspect 2006;114:1205-9.

62. Mahajan R, Blair A, Lynch CF, Schroeder P, Hoppin JA, Sandler DP et al. Fonofos exposure and cancer incidence in the Agricultural Health Study. Environ Health Perspect 2006;114:1838-42.

63. Park RM, Mirer FE. A survey of mortality at two automotive engine manufacturing plants. Am J Ind Med 1996;30:664-73.

64. van der Gulden JWJ. Metal workers and repairmen at risk for prostate cancer - a review. Prostate 1997;30:107-16.

65. Brown D, Delzell E. Motor vehicle manufacturing and prostate cancer. Am J Ind Med 2000;38:59-70.

66. Aronson KJ, Siemiatycki J, Dewar R, Gerin M. Occupational risk factors for prostate cancer: results from a case-control study in Montreal, Quebec, Canada. Am J Epidemiol 1996;143:36373.

67. Fritschi L, Glass DC, Tabrizi JS, Leavy JE, Ambrosini GL. Occupational risk factors for prostate cancer and benign prostatic hyperplasia: a case-control study in Western Australia. Occup Environ Med 2007;64:60-5.

68. Krishnadasan A, Kennedy N, Zhao YX, Morgenstern H, Ritz B. Nested case-control study of occupational chemical exposures and prostate cancer in aerospace and radiation workers. Am J Ind Med 2007;50:383-90.

69. Agalliu I, Kriebel D, Quinn MM, Wegman DH, Eisen EA. Prostate cancer incidence in relation to time windows of exposure to metalworking fluids in the auto industry. Epidemiology 2005;16:664-71.

70. Spinelli JJ, Demers PA, Le ND, Friesen MD, Lorenzi MF, Fang $\mathrm{R}$ et al. Cancer risk in aluminum reduction plant workers
(Canada). Cancer Causes Control 2006;17:939-48.

71. Evanoff BA, Gustavsson P, Hogstedt C. Mortality and incidence of cancer in a cohort of Swedish chimney sweeps - an extended follow up study. Br J Ind Med 1993;50:450-9.

72. Bates MN. Registry-based case-control study of cancer in California firefighters. Am J Ind Med 2007;50:339-44.

73. LeMasters GK, Genaidy AM, Succop P, Deddens J, Sobeih T, Barriera-Viruet $\mathrm{H}$ et al. Cancer risk among firefighters: A review and meta-analysis of 32 studies [Review]. J Occup Environ Med 2006;48:1189-202.

74. Costantino JP, Redmond CK, Bearden A. Occupationally related cancer risk among coke oven workers: 30 years of follow-up. J Occup Environ Med 1995;37:597-604.

75. Krstev S, Baris D, Stewart PA, Hayes RB, Blair A, Dosemeci M. Risk for prostate cancer by occupation and industry - a 24-state death certificate study. Am J Ind Med 1998;34:413-20.

76. Krstev S, Baris D, Stewart P, Dosemeci M, Swanson GM, Greenberg RS et al. Occupational risk factors and prostate cancer in US blacks and whites. A J Ind Med 1998; 34:421-30.

77. Sharma-Wagner S, Chokkalingam A, Malker H, Stone B, McLaughlin J, Hsing A. Occupation and prostate cancer risk in Sweden. J Occup Environ Med 2000;42:517-25.

78. Seidler A, Heiskel H, Bickeboller R, Elsner G. Association between diesel exposure at work and prostate cancer. Scand J Work Environ Health 1998;24:486-94.

79. Lee IP, Suzuki K, Lee SD, Dixon RL. Aryl hydrocarbon hydroxylase induction in rat lung, liver, and male reproductive organs following inhalation exposure to diesel emission. Toxicol Appl Pharmacol 1980;52:181-4.

80. Fertuck KC, Kumar S, Sikka HC, Matthews JB, Zacharewski TR. Interaction of PAH-related compounds with the alpha and beta isoforms of the estrogen receptor. Toxicol Lett 2001;121:167-77.

81. Boffetta P. Methodological aspects of the epidemiological association between cadmium and cancer in humans. in: Nordberg G, Herber R, Alessio L, ed. Cadmium in the Human Environment: Toxicity and Carcinogenicity. Lyon: International Agency for Research on Cancer, 1992:425-34.

82. Doll R. Cadmium in the human environment: closing remarks. In: Nordberg G, Herber R, Alessio L, ed. Cadmium in the Human Environment: Toxicity and Carcinogenicity. Lyon: International Agency for Research on Cancer, 1992:459-64.

83. Sahmoun AE, Case LD, Jackson SA, Schwartz GG. Cadmium and prostate cancer: A critical epidemiologic analysis. Cancer Invest 2005;23:256-63.

84. Waalkes MP. Cadmium carcinogenesis in review [Review]. J Inorg Biochem 2000;79:241-4.

85. Blair A, Rothman N, Zahm S. Occupational cancer epidemiology in the coming decades. Scand J Work Environ Health 1999;25:491-7.

86. Siemiatycki J, Wacholder S, Richardson L, Dewar R, Gérin M. Discovering carcinogens in the occupational environment: methods of data collection and analysis of a large case-referent monitoring system. Scand J Work Environ Health 1987;13:48692.

87. Siemiatycki J. Risk Factors for Cancer in the Workplace. Boca Raton: CRC Press, 1991.

88. Sharpe CR, Siemiatycki J, Parent ME. Activities and exposures during leisure and prostate cancer risk. Cancer Epid Biomark Prev 2001;10:855-60.

89. Bouyer J, Hemon D. Retrospective evaluation of occupational exposures in population-based case-control studies - general overview with special attention to job exposure matrices. Int $\mathrm{J}$ Epidemiol 1993;22(Suppl. 2):S57-S64.

90. Lee IP, Suzuki K. Induction of aryl hydrocarbon hydroxylase activity in the rat prostate glands by 2,3,7,8-tetrachlorodibenzo- 
p-dioxin. J Pharmacol Exp Ther 1980;215:601-5.

91. Waalkes M, Rehm S, Perantoni A, Coogan T. Cadmium exposure in rats and tumours of the prostate. in: Nordberg G, Herber R, Alessio L, ed. Cadmium in the Human Environment: Toxicity and Carcinogenicity. Lyon: International Agency for Research on Cancer, 1992:391-400.

92. Hess-Wilson JK, Knudsen KE. Endocrine disrupting compounds and prostate cancer. Cancer Lett 2006;241:1-12.

93. Sonnenschein C, Soto AM. An updated review of environmental estrogen and androgen mimics and antagonists. J Steroid Biochem Mol Biol 1998;65:143-50.

94. Prins GS, Birch L, Tang WY, Ho SM. Developmental estrogen exposures predispose to prostate carcinogenesis with aging [Review]. Reprod Toxicol 2007;23:374-82.

95. Muir KR. Endocrine-disrupting pesticides and selected hormonally dependent cancers. Scand J Work Environ Health 2005;31:55-61.

96. Barsano CP, Thomas JA. Endocrine disorders of occupational and environmental origin. Occup Med 1992;7:479-502.
97. Colborn T. Endocrine disruption from environmental toxicants. In: Rom W Editor. Environmental and Occupational Medicine. 3rd ed. Philadelphia: Lippincott-Raven Publishers, 1998:80312.

98. DeRosa C, Richter P, Pohl H, Jones DE. Environmental exposures that affect the endocrine system: public health implications. J Toxicol Environ Health Part B 1998;1:3-26.

99. Olea N, Pazos P, Exposito J. Inadvertent exposure to xenoestrogens. Eur J Cancer Prev 1998;7(Suppl 1):S17-23.

100. Nilsson R. Endocrine modulators in the food chain and environment. Toxicol Pathol 2000;28:420-31.

101. Wagner U, Schlebusch H, van der Ven H, van der Ven K, Diedrich K, Krebs D. Accumulation of pollutants in the genital tract of sterility patients. J Clin Chem Clin Biochem 1990;28:683-8.

Marie-Élise Parent is Associate Professor in Epidemiology at INRS-Institut Armand-Frappier, Université du Québec. She graduated from the University of Toronto (M.Sc. 1988) and from the Université de Montréal (Ph.D. 1994). Her main research interests relate to studying the role of environmental, lifestyle and genetic factors in cancer development. She has held career awards from the Fonds de la recherche en santé du Québec, and receives grant support from the Canadian Cancer Society / National Cancer Institute of Canada, and from the Canadian Institutes of Health Research. She is a member of the Board of Directors of the Canadian Society for Epidemiology and Biostatistics. 